\title{
Modeling Acceptance and Usability for Educational Technology: The Conceptual Gaps
}

\author{
Amadin, F. I, Obienu, A. C. and Uduehi, O. M
}

\begin{abstract}
The acceptance of Educational Technology (ET) is considered critical in evaluating the success of its implementation, as access to these innovations alone does not guarantee use, nor does it determine the benefit for the intended user. Despite the growing attention to innovation in several organizations, little attention has been given to innovations and their diffusion in schools. A number of models and theories has been developed and validated in different contexts to help explain the technology adoption. This paper presents the findings of a systematic and comprehensive review of the technology acceptance models for ETs.
\end{abstract}

Keywords - Educational Technology, Technology Adoption, Acceptance Model, Usage Gap.

\section{INTRODUCTION}

The "potential of technology for enhancing education is intuitively compelling" (Teo, 2011; Greenhalgh, et al., 2005). However, views on the value of technology for education range from blue-sky optimism to more doubtful views. Some are of the opinion that technology may be even harmful or wasteful. Between these extremes, researchers acknowledge that technological innovations can, under proper conditions, deliver superior learning, in addition to shaping workforce opportunities (Lonn and Teasley, 2009; Birch and Sankey, 2008; Miller et al., 2000; Shea et al., 2005; Surry and Land, 2000; Zemsky and Massy, 2004). Providing or enabling the use of technological innovations is by itself not enough to allow the realization of all the benefits associated with using them (Hariri and Roberts, 2014). The assumption that the creation of technology would lead to its acceptance is just wrong (Soffer et al., 2010; Zemsky and Massy, 2004). This is because no one would benefit from buying the most powerful computer on the planet if it was left untouched.

It has been well established in technology adoption literature, that technology innovations will not be effective unless it is accepted by the intended users (Mohammad, 2014). According to Teo (2011), "Technology acceptance is user's willingness to engage technology for the tasks it is designed to support". To Chen and Chan (2011), "Technology acceptance is the

Amadin, F. I, Department of Computer Science, University of Benin, Benin City. Nigeria.

Obienu, A. C., Department of Computer Science, Michael and Cecilia Ibru University, Ughelli, Delta State.

Uduehi, O. M, Department of Computer Science, University of Benin, Benin City. Nigeria. approval, favorable reception and ongoing use of newly introduced systems". However, the ability to evaluate the success of these technological innovations depends largely on the number of users and how well they use these innovations. "Researchers and practitioners have strong interest in understanding why people accept/reject information technology so that better methods for designing, evaluating, and predicting how users will respond to new technology can be developed" (Evwiekpaefe et al. 2018; Dillon and Morris, 1996).

Understanding users' acceptance is a key factor for the development and success of educational technologies (Zemsky and Massy, 2004; Venkatesh et al., 2003). Educational Technologies (ETs) are all forms of technological innovations that impact learning. Some salient and meaningful researches show that ETs do exist (Mayes, et al., 2009; Nachmias and Ram, 2009). This include Smart Interactive Whiteboard (Dostal, 2011), Learning Management Sytems such as Edmodo, Moodle, Turninit, (Marchewka, 2007; El-Gayar and Moran, 2006), Google Apps for Education (Yamin and Lee, 2010), Virtual Learning Environment (Van-Raaij and Schepers, 2008), e-Library (Latif et al. 2011), and email system (Yamin and Lee, 2010). However, because they are new and not considered the norm, they tend to be confined and not used (Hariri and Roberts, 2015). Thus, it is needful to understand the reason leading to their acceptance (Rogers, 2003).

Over the years, several studies have been carried out on understanding the factors influencing the acceptance of technological innovations in various settings. From literature, much study has been done to understand technology acceptance in the business context (Venkatesh et al., 2012). This is understandable, given the close connection between the appropriate uses of technology and profit margin. "Several authors have sought to identify the forces that shape users' acceptance so as to influence the design and implementation process, to avoid or minimize resistance or rejection when users interact with technology" (Evwiekpaefe et al. 2018). "This has led to the identification of fundamental psychological and technological constructs underlying acceptance. From these, technology acceptance models have emerged, thus allowing researchers to predict user acceptance of potential technology applications" (Teo, 2011).

\section{TEChNOLOGy ACCEPTANCE Models}

Acceptance models "have a rich heritage stemming from the fields of psychology, sociology and, to a lesser extent, engineering. These models help to measure how people adopt 
new innovations into their daily behavior" (Teo, 2011). In the late eighties, the field of information systems incorporated and expanded on these models whenever a new innovation emerges. "These new innovations emerged during the mass implementation of information systems for use by the majority of employees in order to improve productivity. This phenomenon followed an argument that in order for new innovations to increase productivity, they needed to be accepted by the intended users" (Teo, 2011). However, "when the information systems were implemented, they were not fully accepted and the scale of productive increase expected, was not seen" (Mathieson et al., 2001). As a result, acceptance models came into play to answer why the new innovations were not being accepted.

Several researchers have proposed various theoretical models (See table 1) that could be used to explain technology adoption. Prominent models include the "Technology Acceptance Model" (TAM) developed by Davis et al., (1989); the "Theory of Reasoned Action" (TRA) by Fishbein and Ajzen (1975); the "Theory of Planned Behavior" (TPB) by Ajzen (1991). As of then, "TAM was the most robust and influential model in explaining acceptance of information technology by its users" (Igbaria et al., 1995). However, several researchers including Mathieson et al., (2001) criticized TAM stating that "TAM was limited to the fact that the model assumes usage is volitional, that is, there are no barriers that would prevent an individual from using an information system if he or she chose to do so". However, "there might be situations where users are confronted with lack of facilitating condition, finance, time, etc, which may hinder them from using the technology" (Loo et al., 2009).

To address the shortcomings of TAM, "several researchers (Agarwal and Prasad (1998), Mathieson et al., (2001), Shih (2004), Musa (2006), and Tung et al., (2008)) have attempted to enhance the TAM. Although these studies aimed to enhanced the TAM model by overcoming TAM's limitations. However, it resulted in several fragmentation of the TAM". To this effect, Venkatesh et al., (2003) proposed another model called the "Unified Theory of Acceptance and Use of Technology" (UTAUT) that overcomes the above mentioned limitations.

Among these models, the "UTAUT model is considered to be the most robust, and influential model in explaining acceptance of information technology by its users" (Venkatesh et al, 2003). UTAUT came into play through "the review, mapping and integration of eight dominant theories and models", viz: the "Theory of Reasoned Action" (TRA), the "Technology Acceptance Model" (TAM), the "Motivational Model" (MM), the "Theory of Planned Behaviour" (TPB), a "combined Theory of Planned Behaviour/Technology Acceptance Model" (C-TPB-TAM), the "Model of PC Utilization" (MPCU), the "Innovation Diffusion Theory" (IDT), and the "Social Cognitive Theory" (SCT).

Since its emergence in 2003, UTAUT model has been validated in several organization and cultural contexts. Studies on cultural validation includes "a study on University email system in Malaysia (Yamin and Lee, 2010); employees' acceptance and use of computers in Saudi (Al-Gahtani, et al.,
2007); Internet banking in Korea" (Im et al., 2011). However, among the studies citing UTAUT, "very few implement the full model probing all of its constructs" (Williams, et al., 2011). Supporting this, Venkatesh, et al., (2012) noted that "most studies citing UTAUT employed only a subset of the constructs, referring to the replications and applications of UTAUT". Therefore, "further testing of the complete model is needed" (Fatema, 2013).

Venkatesh et al. (2003) theorizes that "adoption intention has significant positive influence on technological usage in every research settings" (Venkatesh et al. 2003). Supporting this, Lahtinen (2012) argued that UTAUT is fundamentally a general adoption model which is not context-dependent. However, Evwiekpaefe et al. (2018) noted that UTAUT model does not handle specific domains hence the model is constantly being modified or extended. Continuing, they stated that "a model that is focused on a specific class of technology will be more explanatory compared to a general model, that attempts to address many classes of technologies. Such a focused model will provide developers and managers with levers to augment acceptance and use" (Evwiekpaefe, et al. 2018; Brown, et al., 2010). Also, the original UTAUT model focused on the mandatory use of technologies in a work environment. This sometimes makes it difficult using it in voluntary situations (Lahtinen, 2012).

Despite being a robust model, "UTAUT is still open to the addition of other variables/factors that can influence and affect adoption of a certain technologies" (Venkatesh et al., 2003; Liu et al., 2009; Yuen and Ma, 2008; Anandarajan et al., 2010). The "model has often been applied in organizational contexts" (Venkatesh et al., 2012). In the field of education, UTAUT and additional constructs have been applied to explore varying innovations. In a study regarding staff members adoption of learning innovations in UK (Hariri and Roberts, 2015), students' requirement and expectation, innovation visibility were found to significantly determine behavioural intention to adopt learning innovations. Similarly, Oye et al., (2012) provided support for attitude towards using a technology, self-efficacy, and computer anxiety as a determinant in the adoption of instructional technology by university staff members.

The forth observation from the literature review relating to the use of UTAUT is that it failed to capture other important variables supported by technology acceptance literature. Literature on technology in learning institutions have studied the effect of technology awareness (Chiemeke et al., 2014; Dulle and Mineshi-Majanja, 2011; Tibenderana et al., 2010), technology accessibility (Chiemeke and Evwiekpaefe, 2011; Park, 2009), attitude towards using a technology (Oye et al., 2012; Yoo and Huang, 2011; Yamin and Lee, 2010), computer anxiety (Indrati et al., 2014; Oye et al., 2012; Gogus et al., 2012), computer self-efficacy (Indrati et al., 2014; Oye et al., 2012; Yu, 2012), result demostrability (Hariri and Roberts, 2015), among others on the adoption and usage of technology in learning institutions. 
TABLE I: A BRIEF COMPARISON OF THE EXISTING MODELS

\begin{tabular}{|c|c|c|c|c|}
\hline Theory & Brief & Advantage(s) & Disadvantage(s) & $\begin{array}{l}\text { Supporting } \\
\text { Literature }\end{array}$ \\
\hline $\begin{array}{l}\text { "Theory of } \\
\text { Reasoned Action } \\
\text { (TRA) } \\
\text { (Fishbein and Ajzen, 1975)" }\end{array}$ & $\begin{array}{l}\text { "Examines the } \\
\text { relationship between } \\
\text { attitudes and behaviours. } \\
\text { Argues that users' actual } \\
\text { behaviour is influenced } \\
\text { by their intention to } \\
\text { perform that behavior". }\end{array}$ & $\begin{array}{l}\text { a) Influenced many of } \\
\text { the innovation adoption } \\
\text { theories and models (the } \\
\text { intention-behaviour link } \\
\text { specifically). }\end{array}$ & $\begin{array}{l}\text { a) Neglected social related } \\
\text { influences. } \\
\text { b) The model was not } \\
\text { developed within the higher } \\
\text { education context. } \\
\text { c) No attention given to } \\
\text { students' related factors that } \\
\text { may influence adoption. }\end{array}$ & $\begin{array}{l}\text { Hariri and Roberts, } \\
2015\end{array}$ \\
\hline Theory & Brief & Advantage(s) & Disadvantage(s) & $\begin{array}{l}\text { Supporting } \\
\text { Literature }\end{array}$ \\
\hline $\begin{array}{l}\text { "Concerns-based } \\
\text { Adoption model } \\
\text { (CBAM) } \\
\text { (Hall and Hord, 1987)" }\end{array}$ & $\begin{array}{l}\text { A process for } \\
\text { facilitating change } \\
\text { within an educational } \\
\text { context. }\end{array}$ & $\begin{array}{l}\text { The model noted that } \\
\text { technological change is } \\
\text { a process, and not an } \\
\text { event. }\end{array}$ & $\begin{array}{l}\text { a) Assumes that the } \\
\text { organisations are aware of its } \\
\text { resources. } \\
\text { b) Follows a top-down } \\
\text { approach rather than aiming } \\
\text { to understand } \\
\text { adoption from the user's } \\
\text { perspective. } \\
\text { c) Not clear what factors } \\
\text { influence the adoption and } \\
\text { usage of technology. }\end{array}$ & $\begin{array}{l}\text { Hariri and Roberts, } \\
2015\end{array}$ \\
\hline $\begin{array}{l}\text { "Innovation } \\
\text { Diffusion Theory } \\
\text { (IDT) } \\
\text { (Rogers, 1995)" }\end{array}$ & $\begin{array}{l}\text { Based on extensive } \\
\text { literature survey, the } \\
\text { theory Identified key } \\
\text { attributes of innovations } \\
\text { influencing adoption. }\end{array}$ & $\begin{array}{l}\text { a) Influenced many of } \\
\text { the technology adoption } \\
\text { theories and models. }\end{array}$ & $\begin{array}{l}\text { a) No attention were given to } \\
\text { students' related factors that } \\
\text { may influence adoption. }\end{array}$ & $\begin{array}{l}\text { Evwiekpaefe et al., } \\
2018 ; \\
\text { Hariri and Roberts, } \\
\text { 2015; } \\
\text { Kiwanuka, 2015; } \\
\text { Lahtinen, 2012. }\end{array}$ \\
\hline $\begin{array}{l}\text { "Technology } \\
\text { Acceptance Model } \\
\text { (TAM) } \\
\text { (Davis et al., 1989)" }\end{array}$ & $\begin{array}{l}\text { "Adapted from the TRA } \\
\text { model to the information } \\
\text { systems field to help } \\
\text { explain adoption and use } \\
\text { of information systems". }\end{array}$ & $\begin{array}{l}\text { a) Influenced many of } \\
\text { the innovation adoption } \\
\text { theories and models. } \\
\text { b) One of the most used } \\
\text { theories to explain } \\
\text { adoption within many } \\
\text { different contexts. } \\
\text { c) Successful in } \\
\text { predicting more than } \\
40 \% \text { and up to } 70 \% \text { of } \\
\text { technology use. }\end{array}$ & $\begin{array}{l}\text { a) Neglected the social } \\
\text { aspect of the IT acceptance } \\
\text { process. } \\
\text { b) A flaw in the idea that } \\
\text { perceived ease of use can be } \\
\text { mapped directly to the } \\
\text { self-efficacy. } \\
\text { c) The model was not } \\
\text { developed within the higher } \\
\text { education context. }\end{array}$ & $\begin{array}{l}\text { Evwiekpaefe et al., } \\
2018 ; \\
\text { Kiwanuka, 2015; } \\
\text { Hariri and Roberts, } \\
\text { 2015; } \\
\text { Lahtinen, 2012; } \\
\text { Davis et al., 1989 }\end{array}$ \\
\hline Theory & Brief & Advantage(s) & Disadvantage(s) & $\begin{array}{l}\text { Supporting } \\
\text { Literature }\end{array}$ \\
\hline $\begin{array}{l}\text { "Theory of Planned } \\
\text { Behaviour (TPB) } \\
\text { (Ajzen, 1991)" }\end{array}$ & $\begin{array}{l}\begin{array}{l}\text { Suggested } \\
\text { 'perceived }\end{array} \begin{array}{r}\text { adding } \\
\text { behavior }\end{array} \\
\text { control', to overcome } \\
\text { TRA's weakness with } \\
\text { regard to neglecting } \\
\text { social factors and their } \\
\text { possible influence. }\end{array}$ & $\begin{array}{l}\text { a) Influenced many of } \\
\text { the innovation adoption } \\
\text { theories and models. }\end{array}$ & $\begin{array}{l}\text { a) The model was not } \\
\text { developed within the higher } \\
\text { education context. } \\
\text { b) No attention given to } \\
\text { students' related factors that } \\
\text { may influence adoption. }\end{array}$ & $\begin{array}{l}\text { Hariri and Roberts, } \\
2015\end{array}$ \\
\hline $\begin{array}{l}\text { "The } \\
\text { Learning/Adoption } \\
\text { Trajectory Model } \\
\text { (Sherry et al., 2000)" }\end{array}$ & $\begin{array}{l}\text { Concerned with the } \\
\text { adopter's progress and } \\
\text { development } \\
\text { through the innovation } \\
\text { decision cycle as they } \\
\text { gain more knowledge } \\
\text { about the innovation. }\end{array}$ & $\begin{array}{l}\text { a) General technology } \\
\text { acceptance model }\end{array}$ & $\begin{array}{l}\text { a) Not clear what factors } \\
\text { influence the adoption and } \\
\text { diffusion of innovations. } \\
\text { b) Rare mention and support } \\
\text { in the } \\
\text { literature. }\end{array}$ & $\begin{array}{l}\text { Hariri and Roberts, } \\
2015 .\end{array}$ \\
\hline $\begin{array}{l}\text { "The Unified } \\
\text { Theory of } \\
\text { Acceptance and } \\
\text { Use of } \\
\text { Technology } \\
\text { (UTAUT) } \\
\text { (Venkatesh et al., 2003)" }\end{array}$ & $\begin{array}{l}\text { A model that is based on } \\
\text { constructs of eight } \\
\text { established models } \\
\text { including the } \\
\text { aforementioned TRA, } \\
\text { TPB, IDT, TAM and } \\
\text { other theories or models. }\end{array}$ & $\begin{array}{l}\text { a) A global model that } \\
\text { Incorporated and built } \\
\text { on many of the factors in } \\
\text { previous } \\
\text { well-established } \\
\text { theories and models. } \\
\text { b) Successful in } \\
\text { predicting up to } 70 \% \text { of } \\
\text { the variance in the } \\
\text { intention to use. } \\
\text { c) Investigated } \\
\text { mediation and } \\
\text { moderation effects to } \\
\text { highlight their possible } \\
\text { influence on adoption. }\end{array}$ & $\begin{array}{l}\text { a) Does not handle specific } \\
\text { domains. } \\
\text { b) Lack effective use in a } \\
\text { voluntary setting. } \\
\text { c) No attention given to } \\
\text { students related constructs } \\
\text { that may influence adoption. } \\
\text { d) Failed to capture other } \\
\text { important factors supported } \\
\text { by technology adoption } \\
\text { literature. }\end{array}$ & $\begin{array}{l}\text { Evwiekpaefe et al., } \\
\text { 2018; } \\
\text { Kiwanuka, 2015; } \\
\text { Hariri and Roberts, } \\
\text { 2015; } \\
\text { Lahtinen, 2012; } \\
\text { Venkatesh et al., } \\
\text { 2003; }\end{array}$ \\
\hline
\end{tabular}


This raises a question of whether "UTAUT model alone can be effectively used in a learning institution context to predict users' acceptance and use of technology" (Hariri and Roberts, 2015; Mohammad, 2014; Fatema, 2013).

Moreso, previous research shows that the explanatory power of the UTAUT model when used to measure the acceptance of ET usually falls below the $70 \%$ suggested by the Venkatesh et al. (2003). In other words, less than $70 \%$ of the variance in behavioral intention can be explained by the model when used for ET (Mbete and Raisamo, 2014; Thamos et al., 2013; Hsu, 2012; Yeboah et al., 2014). Supporting this, Petter et al., (2008) noted that the current theoretical perspective on user acceptance is very weak in providing prescriptive guidance to researchers when investigating adoption in schools. Straub (2009) further argued that "TAM model or even its successor UTAUT, does not give the full picture whether an individual will adopt a particular ET or not. He claims that technology adoption is a complex, inherently social, developmental process and therefore to successfully facilitate an adoption, an organization has to be able to address individuals' cognitive, affective and contextual interests and concerns".

Against these shortcomings, several researchers including Hariri and Roberts (2015), Chiao-Chen (2013), Oye et al., (2012), Maldonado et al (2011), Latif et al., (2011), Yamin and Lee (2010), Jong and Wang (2009), El-Gayar and Moran, (2006), and several others have attempted to improve UTAUT model towards educational use context. These studies focused to modify/extends the original UTAUT by overcoming UTAUT's limitations. However, their effort resulted in several fragmented models. Our review revealed that researchers are confronted with a choice among several fragmented models and find they must choose a "favoured model" and largely ignore the contributions made from alternative models or "pick and choose" constructs across the existing models. Moreso, the "pick and choose" variables across the existing models when measuring behavior has been observed to be one of the impediments in the IT/IS research (Venkatesh et al. 2012). Obviously, this has posed a problem on the general use of acceptance models since it is not clear which specific model to be adopted for a particular technology (Evwiekpaefe et al., 2018; Kiwanuka, 2015). Against this background, there is a clear need for the development of a generic model, which is capable of predicting the adoption of educational technologies.

\section{PREVIOUS MODIFICATIONS/EXTENSIONS OF UTAUT TOWARDS EDUCATIONAL USE CONTEXT}

This research noted the work of Hariri and Roberts (2015) entitled "Adoption of Innovation within Universities: Proposing and Testing an Initial Model". The motivation for their work was that UTAUT was not developed to explain technology adoption within the learning institution. The aim of their work was to propose a model "Learning Innovation Adoption (LIA) Model", that will aid in predicting technology adoption within UK universities. The proposed LIA model was built on the UTAUT and Rogers's Innovation Diffusion Theory (IDT). The empirical result according to their findings, suggested that the students' requirements and expectations and innovation visibility constructs proposed were found to influence the intention as well as the use of innovations.

The work of Abu-Al-Aish and Love (2013), entitled "Factors Influencing Students' Acceptance of M-Learning: An Investigation in Higher Education", extended the UTAUT model to understand factors/variables likely to influence m-learning acceptance in higher education. This modified model accounted for "Quality of Service" and "Personal innovativeness". Their result reveals that influence of lecturers, performance expectancy, quality of service, personal innovativeness, and effort expectancy were all predictors that affect behavioural intention to use m-learning.

A modified version of UTAUT was also proposed by Oye et al., (2012) to understand the behavioural intention of university staff members to adopt and use ICT in their workplace. Modified UTAUT takes into account computer anxiety, self-efficacy and attitude. Findings indicate that attitude towards using technology is the most influential predictor of university staff members acceptance and use of ICT. Computer anxiety, that is, fear of computer (ICT), also has positive influence on the bahavioural intention of the academic staff members.

To examine adoption and usage of open access within public universities, Dulle and Minishi-Majanja (2011) developed an open access model comprised of six (6) constructs and five (5) moderators. UTAUT model was modified by adding two (2) constructs (Internet self-efficacy attitude) and two moderators (position and awareness). A survey of 544 university researchers at six (6) universities in Tanzania was conducted by them. From their result, effort expectancy, performance expectancy, attitude, and awareness were established as the key predictors for the researchers' behavioral intentions of open access usage. Similarly, social influence, facilitating conditions, awareness, age, and behavioral intention were found to significantly affect researchers' actual usage of open access.

Another work to consider is that of Latif, et al., (2011). They extended UTAUT to investigate postgraduate students' intention to use digital library in Malaysian. Modified UTAUT takes into account "Information quality" and "system quality", as a key determinant of behavioural intention to use and system use. Results reveals significance of performance expectancy, information quality, and effort expectancy, while system quality had no effect on digital library use.

We are also aware of the work of Maldonado et al., (2011) entitled "E-learning motivation and educational portal acceptance in developing countries". The study aimed to further validate a modified UTAUT model by including "e-learning motivation" as a factor in the South American context. The study suggests e-learning motivation and social influence as significant factors on e-portal acceptance, while facilitating condition was not a significant factor on e-learning portal use behavior. Moreso, found was the moderating role of "region" had significant influence on e-LM adoption.

We are also not unmindful of the work done by Yamin and 
Lee (2010), entitled "Level of Acceptance and Factors Influencing Students' Intention to Use UCSI University's E-mail System". The study aim to explore the acceptance level and usability of the newly implemented e-mail system. The study also wants to reveal the relationships between influencing factors and intention to use the e-mail system. The study reveals that the students' acceptance level was low. Meanwhile, strong support was found to the independent variables: effort expectancy, performance expectancy, and attitude towards using technology, to predict the behavioural intention to use the e-mail system.

Another modification of UTAUT was proposed by El-Gayar and Moran, (2006) to evaluate students' acceptance of mobile computing devices Tablet PC. Results showed that variables of self efficacy, performance expectancy, attitude toward using technology, effort expectancy, are key determinants of behavioral intent. Social Influence and Computer anxiety do not appear to have much influence to behavioral intent. Gender, age, experience, and voluntary use are considered as moderating conditions. All moderators, except for experience, were found to not have any effect. Moreso, Computer experience was shown to be the key determinant on the acceptance of technology, which is indicated by the significance found between upper classmen and freshman in the study.

\section{Technology Acceptance Models GaP}

As is the case with any research, these works have a number of limitations. These limitations will be discussed under the following gaps.

\section{Gap 1: Inadequacy of the Extant Models}

The "continuing quest to promote user acceptance is an ongoing management challenge" (Williams, et al, 2015; Schwarz and Chin, 2007), and "one that has engaged IS/IT researchers to such an extent that technology adoption and use research is now considered to be among the main areas of exploration" (Venkatesh et al., 2003). Silva (2006) highlights the importance of not only having a technical view, that is, the requirements offered by technology, but to search with a view to comprehend the behavior of who will use it. In the literature, it is possible to identify numerous models/theories which try to predict the impact of technological innovations in the human behavior. However, early attempts to define technology adoption within schools were ill-defined (Straub, 2009). Hariri and Roberts (2015) argued that the existing models lack the ability to propose appropriate evaluation criteria for learning institutions. Supporting this, Straub (2009) and Petter et al., (2008) noted that the current theoretical perspective on user acceptance is very weak in providing prescriptive guidance to researchers when investigating adoption within schools.

A comprehensive review of 450 citations of the originating article in an attempt to better understand the adaptations and use of UTAUT, as well as the reasons for citation, Williams et.al (2011) revealed that "only 43 actually utilized the model or its constructs in their empirical research for examining IS/IT related issues". This imply that despites its popularity, UTAUT was not employed solely without being modified. Moreso, the explanatory power of the UTAUT model when used within the education context falls below the $70 \%$ suggested by the authors (Mbete and Raisamo, 2014; Hsu, 2012; Thamos et al., 2013; Yeboah et al., 2014), which raises a question of whether UTAUT alone can be effectively used within learning institutions to predict technology acceptance and use (Mohammad, 2014; Odumeru, 2013; Fatema, 2013, Hariri and Roberts, 2015).

Venkatesh, et al. (2003), unlocked ample of opportunities for future studies inoderr to enhance our understanding of technology adoption and usage. They thus suggested; "While the variance explained by UTAUT is quite high for behavioural research, further work should attempt to identify and test additional boundary conditions of the model in an attempt to provide an even richer understanding of technology adoption and usage behaviour. This might take the form of additional theoretically motivated moderating influences, different technologies (e.g., learning innovations, collaborative systems, e-commerce applications), different user groups (e.g., individuals in different functional areas), and other organizational contexts (e.g., public or government institutions)". Interestingly, Tornatzky and Klein (1982) were of the same opinion, thereby, "recommending researchers to look at multiple technology characteristics that allow for a better understanding of predictive power and any inter-relationships".

Taking both recommendations into consideration, Hariri and Roberts (2015) developed a model known as Learning Innovations Adoption Model (LIA Model), that will aid to investigate technology adoption within Universities, as suggested by Venkatesh, et al., (2003) and Tornatzky and Klein (1982). The proposed LIA model was built on the UTAUT and Rogers's Innovation Diffusion Theory (IDT). However, their model could only explain about $30 \%$ of the variance in the behavioural intention to adopt learning innovation. The implication of their result is that there are possibly other important constructs influencing the adoption of learning innovations which were not captured in their study (Hariri and Roberts, 2015). Therefore, this inability of the extant models to adequately measure and evaluate user behavior in Educational Technology regarding acceptance and usage has been identified as a gap.

\section{Gap 2: Choice of a Research Model}

A number of factors relating to user acceptance have been identified and there are inconsistencies in the use of the constructs of the extant models in past studies (Kripannont, 2007). This situation makes it difficult to select a suitable model to use. Findings reveals that there is a trend of using other constructs together with the existing models, to shed light and identify factors likely to influence ET adoption (Mohammad, 2014; Williams et al., 2011). Despites UTAUT wide acceptance, Venkatesh et.al. (2012) incorporated three other variables into UTAUT: Price value, hedonic motivation, and habit, extending UTAUT into UTAUT 2. This is not only applicable to business firms as researchers in the field of educational technology, that adopted any of the existing models, 
had to modify/extend the choice model first before adapting it in their research (Chiao-Chen, 2013; Oye et al., 2012; Nassuora, 2012, El-Gayar and Moran, 2006; Jong and Wang, 2009; Yamin and Lee, 2010; Maldonado et al, 2011; Latif et al., 2011). Hariri and Roberts (2015) extended the UTAUT model to understand factors that influence the acceptance of learning innovations in higher education. Their modified model accounted for 'Students' Requirements and Expectations, Student Learning, Innovation Visibility, Result Demonstrability, as determinant of behavioural intention to adopt learning innovations. Similarly, A modified version of UTAUT was also proposed by Oye et al., (2012), to understand the behavioural intention of university staff members to accept ICT in their workplace. The modified UTAUT takes into account computer anxiety, self-efficacy and attitude towards using technology, as a predictor of behavioural intention in the adoption of instructional technology by university staff members. Another modification to consider is that of Latif, et al., (2011). They extended UTAUT by incorporating "Information quality" and "System quality", as a direct determinant of behavioural intention to use digital library. However, these efforts have resulted in several fragmented models.

Our review revealed that researchers are now confronted with a choice among several models and find they must choose a "favoured models" and largely ignore the contributions from alternative models or "pick and choose" constructs across the models. Obviously, this has posed a problem on the general use of acceptance models since it is not clear which specific model to be adopted for a particular technology. Thus, there is a need for the development of a generic model, which is capable of predicting the adoption of any educational technology. It is hoped that a generic acceptance model for educational technology will address this gap convincingly.

\section{Gap 3: Non-involvement of all Stakeholders}

Another critique of the above mentioned educational technology acceptance models is the non-involvement of all stakeholders of education in acceptance modeling. Despite the use of the UTAUT and its extended/modified models which provide insights into user behavior on technology adoption, "it lacks a mechanism for considering the perspectives of multiple stakeholders and their involvement in the IT adoption in schools" (Lawrence, 2010). Most of the studies used either staff (Hariri and Roberts, 2015; Oye et al., 2012; Ahmad et al, 2010; Yuen et al., 2008) or students (e.g. El-Gayar and Moran, 2006; Jong and Wang, 2009; Yamin and Lee, 2010; Hsu, 2012; Lakhal et al., 2013) as participants. This is defective since institutional learning involves both staff and students to take place. The inability of the extant models to address diverse perceptions of stakeholders (e.g, staff and students) is detrimental to ET adoption success in schools (Benbasat and Barki, 2007). In line with this, Oliveira and Martins (2011) and Lawrence (2010) both noted that "the extant models are deterministic in nature because they fail to recognize the importance of different stakeholder views, which is part of ET adoption and use". Thus, there is a need to understand and validate extant models from both staff and students' perspectives. This will provide a base line assessment for the selection of an appropriate evaluation criterion for learning institutions.

\section{Gap 4: Limited Sample Size}

Determining the reliability of a construct as it applies to a huge population can be unrealistic for certain reasons, so it's common to determine it for a smaller set, called a sample. The sample size reflects "the amount of information we have, as well as, in part, determines our precision or level of confidence that we have in our sample estimates" (Deziel, 2018). "When the sample size is small, it reduces the power of the study and increases the error margin. This in turn can render the whole study worthless" (Marley, 2014). Most of the technology acceptance models were validated with limited sample size. For instance, in the work of Hariri and Roberts (2015), "the response rate of their study was low. As a result of the low response rate, it will be difficult to generalized the findings of their study. Meanwhile, there is a likelihood of the inherent bias where only university staff members who had time or were interested in participating did so" (Hariri and Roberts, 2015). This is not only applicable to their study alone as several adoption models were tested using limited sample size. Thus, there is still need to further validate most of the ETA models with a larger sample.

\section{Gap 5: Need for a Generic Model:}

The state of technology acceptance model in the field of education is fractured and in need of consolidation. Previous studies that adopted UTAUT model and its extensions, "have numerous purpose and methodological variances leading to different conclusions about the applicability of UTAUT in learning institutions" (Fatema, 2013). Our review evidently shows that the decision to adopt (or reject) educational technology is a process involving many factors. However, these constructs are often studied in isolation of each other. Rarely are these constructs examined together under a model to sort out the relevant importance of these constructs and find the relationships among them. It is therefore needful for present technology adoption studies to validate past researches and consolidate the appropriate constructs into a robust model (Venkatesh et al, 2003). 
TABLE II: GAP ANALYSIS OF EdUCATIONAL TECHNOLOGy ACCEPTANCE MODELS

\begin{tabular}{|c|c|c|c|}
\hline Authors & $\begin{array}{l}\text { Variable } \\
\text { Proposed }\end{array}$ & Findings & Conceptual Gap \\
\hline $\begin{array}{l}\text { Hariri and } \\
\text { Roberts (2015) }\end{array}$ & $\begin{array}{l}\text { UTAUT } \\
+ \text { SRE } \\
+ \text { SL } \\
+ \text { RE } \\
+ \text { TR } \\
+ \text { VI }\end{array}$ & $\begin{array}{l}\text { "Findings revealed that SRE and VI are } \\
\text { main predictors of academic staff } \\
\text { acceptance and use learning } \\
\text { innovations". }\end{array}$ & $\begin{array}{l}\text { 1. The model was based on the experience of university staff } \\
\text { only, needs to be validated with from students' perspective. } \\
\text { 2. Although it accounted for educational related factors, it } \\
\text { neglected some of the contributions made by other } \\
\text { researchers. This includes attitude towards using technology, } \\
\text { technology accessibility, technology awareness etc. } \\
\text { 3. Need further empirical validation since most proposed } \\
\text { construct were found insignificance. } \\
\text { 4. This model was tested for limited sample size. }\end{array}$ \\
\hline Author(s) & $\begin{array}{l}\text { Variable } \\
\text { Proposed }\end{array}$ & Findings & Conceptual Gap \\
\hline $\begin{array}{l}\text { "Abu-Al-Aish } \\
\text { and Love" } \\
(2013)\end{array}$ & $\begin{array}{l}\text { "UTAUT" } \\
+ \text { QoS } \\
+ \text { PI }\end{array}$ & $\begin{array}{l}\text { "The results indicate that PE, EE, SI, } \\
\text { QoS, and PI were main significant } \\
\text { factors that affect BI to adopt } \\
\text { m-learning". }\end{array}$ & $\begin{array}{l}\text { 1. This model is based on the experience of students' } \\
\text { perspective only, needs to be validated with from university } \\
\text { staff perspective. } \\
\text { 2. The model assumed that users are aware of the technology } \\
\text { being provided. }\end{array}$ \\
\hline $\begin{array}{l}\text { Chian-Son } \\
(2012)\end{array}$ & $\begin{array}{l}\text { UTAUT } \\
+ \text { PI } \\
+ \text { SL }\end{array}$ & $\begin{array}{l}\text { "SI, PI, SL, PE, and PC significantly } \\
\text { influenced e-library acceptance". }\end{array}$ & $\begin{array}{l}\text { 1. This model lacks the ability to propose appropriate } \\
\text { assessment criteria for learning institutions. } \\
\text { 2. The model was developed to measure the acceptance of a } \\
\text { single technology (e-library acceptance). }\end{array}$ \\
\hline $\begin{array}{l}\text { Oye, et al., } \\
(2012)\end{array}$ & $\begin{array}{l}\text { UTAUT } \\
+ \text { AX } \\
+ \text { SE } \\
+ \text { ATUT }\end{array}$ & $\begin{array}{l}\text { "Findings indicate that PE, AX and } \\
\text { ATUT are the most influential } \\
\text { predictors of ICT acceptance and use". }\end{array}$ & $\begin{array}{l}\text { 1. The model was developed to measure only staff members } \\
\text { acceptance of ICT. } \\
\text { 2. The model assumed that users are aware of the technology } \\
\text { being provided } \\
\text { 3. It failed to account for SRE and VI, which has been proven to } \\
\text { predict users' acceptance. }\end{array}$ \\
\hline $\begin{array}{l}\text { Latif, et al., } \\
\text { (2011) }\end{array}$ & $\begin{array}{l}\text { UTAUT } \\
+ \text { IQ } \\
+ \text { SQ }\end{array}$ & $\begin{array}{l}\text { "Finding reveals that PE, EE and IQ are } \\
\text { positively related to the BI to use digital } \\
\text { library". }\end{array}$ & $\begin{array}{l}\text { 1. The model was developed to measure students' acceptance of } \\
\text { digital library. } \\
\text { 2. The theoretical perspective on user acceptance is very weak in } \\
\text { providing prescriptive guidance to researchers when } \\
\text { investigating adoption in schools. } \\
\text { 3. The model neglected the contributions made by other } \\
\text { researchers. }\end{array}$ \\
\hline $\begin{array}{l}\text { Maldonado et } \\
\text { al., } \\
(2011)\end{array}$ & $\begin{array}{l}\text { UTAUT } \\
+ \\
\text { e-LM }\end{array}$ & $\begin{array}{l}\text { "The study suggests e-LM and SI as a } \\
\text { significant on e-portal acceptance". }\end{array}$ & $\begin{array}{l}\text { 1. The model is silent about several factors relating to } \\
\text { staff/students' acceptance. } \\
\text { 2. This model does not give the full picture whether an } \\
\text { individual will adopt a particular technology or not. }\end{array}$ \\
\hline $\begin{array}{l}\text { Dulle and } \\
\text { Minishi-Majanj } \\
\text { a (2011) }\end{array}$ & $\begin{array}{l}\text { UTAUT } \\
+ \text { TA } \\
+ \text { ISE } \\
+ \text { ATUT }\end{array}$ & $\begin{array}{l}\text { "Amongst their findings, PE, EE, } \\
\text { ATUT, and TA, were established as the } \\
\text { key determinants for the researchers' BI } \\
\text { of open access usage". }\end{array}$ & $\begin{array}{l}\text { 1. No further empirical work carried out to validate the model. } \\
\text { 2. The model was developed specifically for open access usage. }\end{array}$ \\
\hline Author(s) & $\begin{array}{l}\text { Variable } \\
\text { Proposed }\end{array}$ & Findings & Conceptual Gap \\
\hline $\begin{array}{l}\text { Yamin and Lee } \\
(2010)\end{array}$ & $\begin{array}{l}\text { UTAUT } \\
+ \text { VU } \\
+ \text { AX } \\
+ \text { SE } \\
+ \text { ATUT }\end{array}$ & $\begin{array}{l}\text { "Finding reveals that ATUT, EE, and PE } \\
\text { are the main predictors of BI to use the } \\
\text { stud e-mail system". }\end{array}$ & $\begin{array}{l}\text { 1. The model was developed to measure the acceptance and use } \\
\text { of university e-mail system. } \\
\text { 2. The model is weak in providing directions for improvements } \\
\text { in learning institution. }\end{array}$ \\
\hline $\begin{array}{l}\text { Giannakos and } \\
\text { Panayiotis } \\
(2011)\end{array}$ & $\begin{array}{l}\text { UTAUT } \\
+ \text { SCT } \\
+ \text { TPB }\end{array}$ & $\begin{array}{l}\text { "Learners who are using longer } \\
\text { webcasts have significant higher levels } \\
\text { of Behavioural Intention to use it. Social } \\
\text { influence and Performance Expectancy } \\
\text { are influenced by Webcast duration". }\end{array}$ & $\begin{array}{l}\text { 1. The model was developed mainly for the adoption and use of } \\
\text { a single technology. } \\
\text { 2. The literature lacks further research validating and supporting } \\
\text { the use of the model. }\end{array}$ \\
\hline $\begin{array}{l}\text { Pynoo, et al., } \\
\text { (2011) }\end{array}$ & UTAUT & $\begin{array}{l}\text { "PE and SI appeared to be the main } \\
\text { predictors of DLE. EE and FC are of } \\
\text { minor importance UB predicted by } \\
\text { Attitude and BI". }\end{array}$ & $\begin{array}{l}\text { 1. The education specific factors were not measured in the } \\
\text { original UTAUT model, thereby rendering UTAUT } \\
\text { inefficient within the higher-education context. }\end{array}$ \\
\hline $\begin{array}{l}\text { Marchewka et } \\
\text { al., } \\
\text { (2007) }\end{array}$ & "UTAUT" & $\begin{array}{l}\text { "Finding reveals that } \mathrm{EE} \text { and } \mathrm{SI} \\
\text { influence BI to use course management } \\
\text { software". }\end{array}$ & $\begin{array}{l}\text { 1. The model was not developed within the higher education } \\
\text { context } \\
\text { 2. There is a trend of using other constructs alongside with the } \\
\text { existing models, to shed light and identify factors likely to } \\
\text { influence ET adoption }\end{array}$ \\
\hline $\begin{array}{l}\text { El-Gayar and } \\
\text { Moran (2006) }\end{array}$ & $\begin{array}{l}\text { UTAUT } \\
+ \text { SE } \\
+ \text { ATUT } \\
+ \text { ANX }\end{array}$ & $\begin{array}{l}\text { "Results showed that variables of PE, } \\
\text { EE, ATUT, SE are key components of } \\
\text { Behavioral Intent". }\end{array}$ & $\begin{array}{l}\text { 1. The model was mainly to evaluate users' acceptance of } \\
\text { mobile computing devices Tablet PC. } \\
\text { 2. The model neglected the contributions made by other } \\
\text { researchers. }\end{array}$ \\
\hline
\end{tabular}


Key: ATUT - Attitudes Towards Use of Technology, CAX - Computer Anxiety, e-LM - E-learning motivation, ISE - Internet Self Efficacy, IQ - Information Quality, CSE - Computer Self Efficacy, SRE - Student Requirements and expectation. SL- Student Learning, SQ- Systems Quality, QoS - Quality of Service, PI Personal Innovativeness, TA - Technology Awareness, IV - Innovation Visibility, VU - Voluntariness of Use.

In addition, no model was found in the existing literature that captures the dynamic nature of the technology adoption process within schools. The norm was to modify/extends directly from the list of existing models to predict the adoption and use of a single technology. For instance, Latif, et al. (2011) extended UTAUT to investigate postgraduate students' intention to use digital library in Malaysian. Likewise, the work of Abu-Al-Aish and Love (2013), extended the UTAUT model to understand factors that influence the acceptance of m-learning in higher education. However, most of the modified models were targeted on the acceptance and use of a single technology (Oye et al., 2012; Latif et al., 2011; Yamin and Lee, 2010; El-Gayar and Moran, 2006).

Meanwhile, the "pick and choose" constructs across the models when measuring behavior has also been observed to be one of the impediments in the IT/IS research (Venkatesh et al. 2012). It is therefore questioned if the models of acceptance and usage that were developed, modified and extended for a particular technology in a specific environment can be adequately used with its predefined dimensions in a changing technology/environment. Obviously, this has posed a limitation on the general use of acceptance models since it is not clear which specific model to be adopted to accomplish a specific goal. Thus, there is a need for the development of a generic model, which is capable of predicting the adoption of any educational technology. By doing so, future researchers would need not to search, collate and integrate constructs from different models but instead could just apply the generic model to gain an understanding of a variety of problems related to educational technology adoption.

\section{DISCUSSION}

While ET deployment and development in Nigeria continues to increase, experiences and benefits of ET have largely not been widespread (Oye et al., 2012; Petter et al., 2008). Although the use of these innovations may help learning institutions improve their services, but that may not guarantee their usage by the intended users (Amadin and Obienu, 2016). Thus, the process of getting them to accept and use these learning innovations is equally important. The "unending quest to promote user acceptance is an ongoing management challenge" (Williams, et al, 2015; Schwarz and Chin, 2007), and "one that has engaged IS/IT researchers to such an extent that technology adoption and use research is now considered to be among the main areas of exploration" (Venkatesh et al., 2003).

Despite several models on factors influencing ET adoption, challenges still persist (Jokonya, 2015; Hariri and Roberts, 2015; Martins et al. 2010). This has impelled several researchers to question the fitness of the existing models for this intricate issue in Information Systems (IS) research. The existing models and theories therefore seems to have several limitations in addressing technology adoption issuess faced by educational institutions (Petter et al., 2008). Early attempts to define technology adoption within schools were ill-defined (Straub, 2009). Supporting this, Hariri and Roberts (2015) noted that the existing models lack the ability to propose appropriate evaluation criteria for learning institutions. They further argued that the existing models did not address technology adoption in schools as no educational-related constructs were tested, indicating a possible gap for researchers to fill. Our intention in this paper was to analyze the gap in modeling technology acceptance in schools. This study presents the findings of a systematic and detailed review of UTAUT and its extensions to education use context. Based on a review of papers identified from various internet sources such as Google Scholar, Science Direct, and Researchgate, the gaps were presented in terms of five major aspects: inadequacy of extant models, choice of research model, non-involvement of all stakeholders, limited sample size, and Need for a generic model.

From our review, findings revealed that there is a trend of using other constructs alongside with the existing models, to shed light and identify factors likely to influence ET adoption (Mohammad, 2014; Williams et al., 2011). Researchers in the field of ET, that adopted any of the existing models, had to modify/extend the choice model first before adapting it in their research (Chiao-Chen, 2013; Oye et al., 2012; Nassuora, 2012, El-Gayar and Moran, 2006; Jong and Wang, 2009; Yamin and Lee, 2010; Maldonado et al, 2011; Latif et al., 2011). However, this effort has resulted in several fragmented models. Our review reveals that researchers are now confronted with a choice among several of models, of which they must choose a "favoured models" and largely ignore the contributions from alternative models or "pick and choose" constructs across the models.

Moreover, no model was found in the literature that captures the dynamic nature of the technology adoption process within schools. The norm was to modify/extends the choice models to predict the adoption and use of a single technology. Clearly, there is a need for a generic acceptance model that could help predict technology adoption within schools. By doing so, future researchers would need not to search, collate and integrate constructs from different models but instead could just apply the generic model to gain an understanding of the issues related to ET adoption and use. Otherwise, users' acceptance may be less likely (Nachmias and Ram, 2009; Zemsky and Massy, 2004).

\section{CONCLUSION}

The following salient gaps emerged from the findings presented in this study: (1) Inadequacy of extant models, (2) choice of a research model, (3) limited sample size, (4) non-involvement of all stakeholders, (5) Need for a generic model. It is suggested that the study is pertinent in that UTAUT model and its extensions offers a useful tool by which to evaluate the success of ET initiation and helps identify key 
issues likely to influence adoption and use of ET. Our systematic review contributes to the area of ET adoption and use research highlighting various gaps, including identifying trends in ET adoption models. Such a review may inform educationists, researchers, as well as guide suitable future choice of a research model. It is therefore hoped that a generic acceptance model for ET will address these gaps convincingly.

\section{REFERENCES}

[1] Abu-Al-Aish, A. and Love, S. (2013). Factors Influencing Students' Acceptance of M-Learning: An Investigation in Higher Education. The International journal of review of research in open and distance learning. Vol 14, No. 5, Pp 82-107 https://doi.org/10.19173/irrodl.v14i5.1631

[2] Agarwal, R. and Prasad, J. (1998). "A conceptual and operational definition of personal innovativeness in the domain of information technology," Information Systems Research, vol. 9, pp. 204-215. https://doi.org/10.1287/isre.9.2.204

[3] Ajzen, I. (1991). The theory of planned behavior. Organizational Behavior and Human Decision Processes, 50(2), 179-211. https://doi.org/10.1016/0749-5978(91)90020-T

[4] Al-Gahtani, S. S., Hubona, G. S., and Wang, J. (2007). Information technology (IT) in Saudi Arabia: Culture and the acceptance and use of IT. Information \& Management, 44(8), 681-691. https://doi.org/10.1016/j.im.2007.09.002

[5] Anandarajan, M., Zaman, M., Dai, Q., and Arinze, B. (2010). Genaration $Y$ adoption of instant messaging: An examination of the impact of social usefulness and media richness on use richness. IEEE Transactions on Professional Communication, 53(2), 132-143. https://doi.org/10.1109/TPC.2010.2046082

[6] Benbasat, I. and Barki, H. (2007). Qua vadis TAM? Journal of the Association for Information Systems, 8(4), 211-218. https://doi.org/10.17705/1jais.00126

[7] Chian- Son, Y. (2012). " Factors Affecting Individuals to Adopt Mobile Banking: Empirical Evidence from the UTAUT model", Journal of Electronic Commerce Research, 13(2), 2012.

[8] Chiemeke S. C. and Evwiekpaefe A. E, (2011). A conceptual framework of a modified unified theory of acceptance and use of technology(UTAUT) Model with Nigerian factors in E-commerce adoption. International Research Journals, Vol 2, No. 12, pp. 1719-1726.

[9] Chiemeke S. C., Evwiekpaefe, A. E., Okpo, J. A. and Irhebhude, M. E. (2014). A Framework For Electronic Commerce Adoption: A Study In Kaduna State, Nigeria. Science World Journal, 9 (3). Pp 20-26

[10] Davis, F. D., Bagozzi, R. P., and Warshaw, P. R. (1989). User Acceptance Of Computer Technology : A Comparison Of Two. Management Science, 35(8), 982-1003. Retrieved from http://0-search.proquest.com.pugwash.lib.warwick.ac.uk/docview/2132 29133 ? accountid $=14888$ https://doi.org/10.1287/mnsc.35.8.982

[11] Deziel, C. (2018). The Effects of a Small Sample Size Limitation. Retrieved

from https://sciencing.com/effects-small-sample-size-limitation-8545371.htm 1

[12] Dulle, F. W. and Minishi-Majanja, M. K (2011). The suitability of the Unified Theory of Acceptance and Use of Technology (UTAUT) model in open access adoption studies, $\|$ Information Development, vol. 27, no.1, pp. 32-45. https://doi.org/10.1177/0266666910385375

[13] El-Gayar, O. F, and Moran, M (2006). "College students' acceptance of Tablet PCs: An application of the UTAUT Model," Dakota State University, pp. 2845-2850.

[14] Evwiekpaefe, A.E., S.C. Chiemeke, and M.Z. Haruna. (2018). "Individual and Organizational Acceptance of Technology Theories and Models: Conceptual Gap and Possible Solutions". Pacific Journal of Science and Technology. 10(2):189-197.

[15] Fatema, A. (2013). What affects students' acceptance and use of technology? A test of UTAUT in the context of higher-education institution in qatar, Journal of Carnrgir Mellon University. Available online http://repository.cmu.edu/cgi/viewcontent.cgi?article=1168\&context=hs shonors

[16] Fatema, A. (2013). What affects students' acceptance and use of technology? A test of UTAUT in the context of higher-education institution in qatar, Journal of Carnrgir Mellon University. Available online

http://repository.cmu.edu/cgi/viewcontent.cgi?article=1168\&context=hs shonors

[17] Fishbein, M., and Ajzen, I. (1975). Belief, Attitude, Intention, and Behavior: An Introduction to Theory and Research. Reading, Mass.: Addison-Wesley Pub. Co.

[18] Gogus, A., Nistor, N., and Lerche, T. (2012). Educational Technology Acceptance across Cultures: A Validation of the Unified Theory of Acceptance and Use of Technology in the Context of Turkish National Culture. Turkish Online Journal of Educational Technology, 11(4). Retrieved http://www.eric.ed.gov/ERICWebPortal/detail?accno=EJ989305

[19] Greenhalgh, T., Robert, G., Macfarlane, F., Bate, P., and Kyriakidou, O. (2005). Diffusion of innovations in health service organisations : a systematic literature review. Malden, Mass.: Blackwell. https://doi.org/10.1002/9780470987407

[20] Hariri, A., and Roberts, P. (2015). Adoption of Innovation within Universities: Proposing and Testing an Initial Model. Creative Education, 6, 186-203. http://dx.doi.org/10.4236/ce.2015.62017

[21] Hsu, H. (2012). The Acceptance of Moodle: An Empirical Study Based on UTAUT, Scientific research. Vol 3, 44-46.

[22] Igbaria, M; Guimaraes, T; and Davis, G. (1995). "Testing the determinants of microcomputer usage via a structural equation model," Journal of Management Information Systems, vol. 11, pp. 87-114. https://doi.org/10.1080/07421222.1995.11518061

[23] Im, I., Hong, S., and Kang, M. S. (2011). An international comparison of technology adoption: Testing the UTAUT model. Information \& management,48(1), 1-8. https://doi.org/10.1016/j.im.2010.09.001

[24] Indrati, A.; Minaji, E.; Binastuti, S., and Raharjo, P. D. (2014) Comparation of Model Unified Theory of Acceptance and Use Technology (UTAUT) and Technology Acceptance Model (TAM) for Internet Adoption of Credit Union Staff,\| in proc. of The First International Credit Union Conference on Social Micro Finance and Community Development, BKCU Kalimantan - Gunadarma University, pp.64-69.

[25] Jokenya, O. (2015). Validating Technology Acceptance Model (TAM) during IT adoption in Organizations. $7^{\mathrm{TH}}$ International Conference on Cloud Computing Technology and Science. IEEE Computer Society 2015, pp 509-516. https://doi.org/10.1109/CloudCom.2015.56

[26] Jong, D., and Wang, T. S (2009). "Student acceptance of web-based learning system," Paper presented at the 2009International Symposium on Web Information Systems and Applications (WISA'09), Nanchang, People'sRepublic of China, May 22-24.

[27] Kiwanuka, A. (2015). "Acceptance Process: The Missing Link between UTAUT and Diffusion of Innovation Theory". American Journal of Information Systems. 3(2):40-44.

[28] Lahtinen, M. (2012). "E-Invoice Adoption in Organisation". Department of Marketing, Hanken School of Economics: Helsinki, Finland.

[29] Lakhal, S., Khechine, H., and Pascot, D. (2013). Student behavioural intentions to use desktop video conferencing in a distance course: integration of autonomy to the UTAUT model. Journal of Computing in Higher Education, 25(2), 93-121. https://doi.org/10.1007/s12528-013-9069-3

[30] Lawrence, J. (2010). The Factorss that Influence Adoption and Usage Deision in SMEs: Evaluating Interpretive Case Study Research in Information Systems. The Electronic Journal of Business Research Methods, 2010, 8(1), 51-62.

[31] Latif, A.; Adnan, J.; and Zamalia, M. (2011). Intention to Use Digital Library based on Modified UTAUT Model: Perspectives of Malaysian Postgraduate Students. World Academy of Science, Engineering and Technology.

[32] Lewis, C. C.; Fretwell, C. E.; Ryan, J. and Parham, J. B. (2013). Faculty Use of Established and Emerging Technologies in Higher Education: A Unified Theory of Acceptance and Use of Technology Perspective, International Journal of Higher Education, vol. 2, no. 2, pp.22-34. 
https://doi.org/10.5430/ijhe.v2n2p22

[33] Liu, S., Liao, H., and Pratt, J. A. (2009). Impact of media richness and flow on e-learning technology acceptance. Computers and Education, $52(4), 599-607$. https://doi.org/10.1016/j.compedu.2008.11.002

[34] Liu, X. (2010). Empirical testing of a theoretical extension of the technology acceptance model:An exploratory study of educational wikis. Communication Education, 59(1). 52-69. https://doi.org/10.1080/03634520903431745

[35] Loo, W. H; Yeow, P. H. P; and Chong, S. C. (2009). "User acceptance of Malaysian government multipurpose smartcard applications," Government Information Quarterly, vol. 26, pp. 358-367. https://doi.org/10.1016/j.giq.2008.07.004

[36] Maldonado U. P. T , Khan G. F, Moon J, and Rho J. J. (2011). E-learning motivation and educational portal acceptance in developing countries , Online Information Review Volume: 35, 2011

[37] Marley, S. (2014). The Importance and Effect of Sample Size. Retrieved from https://select-statistics.co.uk/blog/importance-effect-sample-size/

[38] Martins, L. L., and Kellermanns, F. W. (2004). A model of business school students' acceptance of a web-based course management system. Academy of Management Learning \& Education, 3(1), 7-26. https://doi.org/10.5465/amle.2004.12436815

[39] Martins, L. M; Moura, A; Cunha, P. R; and Figueiredo, A. D. (2010). Selecting and Ranking IT Governance Practices for Electric Utilities; Proceedings of the Americas Conference on Information Systems, Lima, Peru.

[40] Mathieson, K; Peacock, E; and Chin, W. (2001). "Extending the technology acceptance model: The influence of perceived user resources," The database for advances in information systems, vol. 32, pp. 86-112. https://doi.org/10.1145/506724.506730

[41] Mbete, J. S. and Raisamo, R. "Investigating students" behavioral intention to adopt and use mobile learning in higher education in East Africa", International Journal of Education and Development using Information and Communication Technology (IJEDICT), , Vol. 10, Issue 3, pp. 4-20, 2014.

[42] Mohammad, I. A. (2014). Unified Theory of Acceptance and Use of Technology (UTAUT), A decade of Validation and Development. Fourth International Conference on ICT in our lives 2014 -Information Systems Supporting Decision Making” (ISSN 2314-8942), Information Systems and Computer Science Department, Faculty of Commerce, Alexandria University, Alexandria, Egypt, December 20-22, 2014.

[43] Musa, P. F. (2006). "Making a case for modifying the technology acceptance model to account for limited accessibility in developing countries,"Information technology for development, vol. 12, pp. 213-224, 2006. https://doi.org/10.1002/itdj.20043

[44] Nachmias, R., and Ram, J. (2009). Research Insights from a Decade of Campus-Wide Implementation of Web-Supported Academic Instruction at Tel Aviv University. International Review of Research in Open and Distance Learning, 10(2). https://doi.org/10.19173/irrodl.v10i2.595

[45] Nassuora, A. B. (2012), "Students Acceptance Of Mobile Learning For Higher Education In Saudi Arabia" International Journal of Learning Management Systems 1, No. 1, 1-9, 2012. https://doi.org/10.12785/ijlms/010101

[46] Odumeru, J. A. (2013). Going Cashless : Adoption Of Mobile Banking In Nigeria. Arabian Journal of Business and Management Review, 1(2), 9-17. https://doi.org/10.12816/0003615

[47] Oliveira, T., and Martins, M. F (2011). Literature Review of Information Technology Adoption Models at Firm Level. The Electronic Journal Information System Evaluation, 14(1), 110-121.

[48] Oye, N., A.Iahad, N., and Ab.Rahim, N. Z. (2012). The Impact of UTAUT Model and ICT Theoretical Framework on University Academic Staff: Focus on Adamawa State University, Nigeria. International Journal of Computers \& Technology, 2(2), 102-111.

[49] Park, S. Y. (2009). An Analysis of the Technology Acceptance Model in Understanding University Students' Behavioral Intention to Use e-Learning. Educational Technology \& Society, 12 (3), 150-162.

[50] Petter, S., DeLone, W. and McLean, E. (2008). Measuring information systems success: models, dimensions, measures,and interrelationships. European Journal of Information Systems (2008) 17, 236-263 https://doi.org/10.1057/ejis.2008.15

[51] Rogers, E. (1995). Diffusion of Innovations, Free Press, New York. 1995

[52] Rogers, E. M. (2003). Diffusion of innovations. New York: Free Press.

[53] Shih, H. P. (2004). "Extended technology acceptance model of internet utilization behavior," Information and Management, vol. 41, pp. 719-729, 2004 https://doi.org/10.1016/j.im.2003.08.009

[54] Soffer, T., Nachmias, R., and Ram, J. (2010). Diffusion of Web Supported Instruction in Higher Education - The Case of Tel-Aviv University. Educational Technology \& Society, 13(3), 212-223.

[55] Straub, E. T. (2009). Understanding Technology Adoption: Theory and Future Directions for Informal Learning. Review of Educational Research, 79(2), 625-649. doi:10.3102/0034654308325896

[56] Sumak, B., Polancic, G., and Hericko, M. (2010). An Empirical Study of Virtual Learning Environment Adoption Using UTAUT. In 2010 Second International Conference on Mobile, Hybrid, and On-Line Learning (pp. 17-22). IEEE.

[57] Suoranta, M. (2003). Adoption of Mobile Banking in Finland. Jyväskylä Studies in Business and Economics. University of Jyväskylä. Retrieved from

https://jyx.jyu.fi/dspace/bitstream/handle/123456789/13203/951391654 5.pdf? sequence $=1$

[58] Teo, T. (2011). Technology Acceptance in Education: Research and Issues. Sense Publishers. Nanyang Technological University. Singapore. ISBN: 978-94-6091-485-0 https://doi.org/10.1007/978-94-6091-487-4_1

[59] Thomas, T. D., Singh, L., \& Gaffar, K. (2013). The utility of the UTAUT model in explaining mobile learning adoption in higher education in Guyana. International Journal of Education and Development Using Information and Communication Technology (IJEDICT), 9(3), 71-85.

[60] Tibenderana, P.; Ogao, P.; Ikoja-Odongo, J. and Wokadala, J. (2010). Measuring Levels of End-Users' Acceptance and Use of Hybrid Library Services, International Journal of Education and Development using Information and Communication Technology IJEDICT, vol. 6, no. 2, pp. 33-54.

[61] Tornatzky, L. and K. Klein. (1982) "Innovation Characteristics and Innovation Adoption-Implementation: A Meta-Analysis of Findings", IEEE Transactions on Engineering Management, 29(1), pp. 28-45. https://doi.org/10.1109/TEM.1982.6447463

[62] Tung, F. C; Chang, S. C; and Chou, C. M. (2008). "An extension of trust and TAM model with IDT in the adoption of the electronic logistics information system in HIS in the medical industry," International Journal of Medical Informatics, vol. 77, pp. 324-335. https://doi.org/10.1016/j.ijmedinf.2007.06.006

[63] Venkatesh, A., Morris, M. G., and Davis, G. B. (2003), User acceptance of information technology: Toward a unified view, MIS Quarterly, vol. 27(3), pp. 425-478 https://doi.org/10.2307/30036540

[64] Venkatesh, V; Thong, L.; and Xu, X. (2012) Consumer Acceptance and Use of Information Technology: Extending The Unified Theory of Acceptance and Use Of Technology.MIS Quarterly, 36 (1) pp.157-178. https://doi.org/10.2307/41410412

[65] Williams, M .D.; Rana, N. P; and Dwivedi, Y. K, (2015). "The unified theory of acceptance and use of technology (UTAUT):A literature review", Journal of Enterprise Information Management, 28(3) pp.443488 https://doi.org/10.1108/JEIM-09-2014-0088

[66] Williams, M. D., Rana, N. P., Dwivedi, Y. K., and Lal, B. (2011). Is UTAUT really used or just cited for the sake of it? A systematic review of citations of UTAUT's originating article. In ECIS Proceedings.

[67] Yamin, M. and Lee, Y (2010). "Level of Acceptance and Factors Influencing Students' Intention to Use UCSI University's E-mail System". 2010 International Conference on User Science and Engineering. https://doi.org/10.1109/IUSER.2010.5716717

[68] Yeboah A., Moore, G., and Benbasat, I. (2014). Development of an Instrument to Measure The Perceptions of Adopting an Innovation Technology Innovation, Information Systems Research, vol. 2, no. 3, pp.192-222.

[69] Yoo, S. J. and Huang, W. D. (2011). Comparison of Web 2.0 Technology Acceptance Level based on Cultural Differences, Educational Technology \& Society, vol. 14, no. 4, pp. 241-252. 
[70] Yu, C. (2012). Factors Affecting Individuals to Adopt Mobile Banking: Empirical Evidence from the UTAUT Model, Journal of Electronic Commerce Research, vol. 13, no. 2, pp.104-121.

[71] Yuen, A. K., and Ma, W. K. (2008). Exploring teacher acceptance of e-learning technology. Asia-Pacific Journal of Teacher Education, 36(3), 229-243.

https://doi.org/10.1080/13598660802232779

[72] Zemsky, R., and Massy, W. (2004). Thwarted Innovation: What Happened to elearning and Why. a final report for the Westherstation Project of The Pennsylvania. Retrieved from http://scholar.google.com/scholar?hl=en\&btnG=Search\&q=intitle:Thwa rted+Innovation:+What+Happened+to+e-learning+and+Why\#5 